\title{
Maxillary Sinusitis Mimicking Bone Metastasis in a Patient with MEN 2A
}

\author{
Aylin Akbulut*, F Nur Aydinbelge, Gokhan Koca and Meliha Korkmaz \\ Department of Nuclear Medicine, University of Health Sciences, Ankara Training and Research Hospital, Ankara, Turkey
}

Submission: August 28, 2018; Published: September 18, 2018

*Corresponding author: Aylin Akbulut, Department of Nuclear Medicine, University of Health Sciences, Ankara Application and Research Hospital, Turkey, Tel: +90 5336461631, Fax: +90 31259538 56; Email: aylinbaskin@gmail.com

Abstract

We present a bone scintigraphy of maxillary sinusitis mimicking osteoblastic bone metastasis in a patient with Multiple Endocrine Neoplasia. The clinical presentation and the maxillofacial CT were concordant with maxillary sinusitis. This case represents a rare scintigraphic appearance of maxillary sinusitis in a patient with malignancy.

\section{Introduction}

Bone scintigraphy is very sensitive for detection of metastatic disease in patients with known neoplasms and tracer-avid osseous lesions in bone scintigraphy are usually considered to represent metastases in patients with malignancies. However, other than metastatic disease focal scintigraphic abnormalities are nonspecific and may represent skeletal trauma and less commonly a variety of benign infectious diseases [1]. Here, we are reporting a case with maxillary sinusitis mimicking bone metastases of medullary thyroid carcinoma.

\section{Case Report}

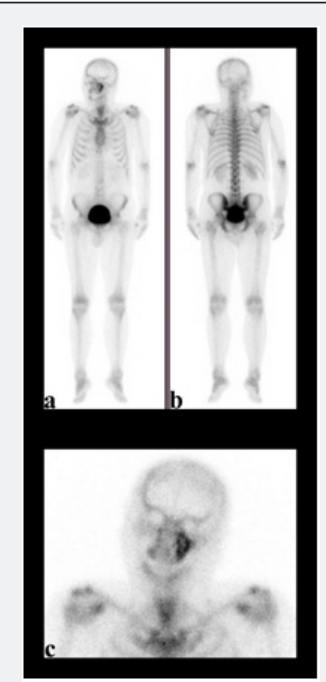

Figure 1: Whole-body bone scintigraphy a) anterior b) posterior position c) static head and neck view presenting increased radioactivity uptake at left maxillary sinus wall.
A 53-year-old male patient with complains of swelling and pain on the face referred to our hospital. In his history, he had bilateral adrenalectomy performed 4 years ago due to bilateral pheochromocytoma and thereafter the patient was using prednisolon $2 \times 5 \mathrm{mg}$. At first, the cause of the swelling and pain was thought to be due to iatrogenic Cushing syndrome and the dose of prednisolone was reduced by $1 \times 5 \mathrm{mg}$. However, no change was observed. Subsequently with the suspicion of the recurrence of pheochromocytoma, abdominal MRI was performed. Abdominal MRI showed a nodular structure compatible with a recurrent tissue of $8 \mathrm{~mm}$ in the right adrenal space and regarding that Multiple Endocrine Neoplasia (MEN) 2A syndrome was suspected. The serum calcitonin level was high (calcitonin: $399 \mathrm{pg} / \mathrm{mg}$ ). The neck ultrasound revealed a suspected nodule and the fine needle aspiration biopsy was concordant with medullary thyroid carcinoma and the patient was considered as MEN2A syndrome. He was referred to bone scintigraphy due to facial pain, with suspicion of bone metastasis. The scintigraphy displayed diffuse increased radioactivity limited in the left maxillary sinus wall (Figure 1). Consequent, maxillofacial CT was showed sinusitis in left maxilla. The physical examinations at ear nose throat clinic (ENT) were consistent with maxillary sinusitis. He received antibiotics for maxillary sinusitis and his symptoms were disappeared. Afterwards, the patient was reoperated for residual adrenal disease and thyroidectomy was performed for medullary thyroid carcinoma. He is still in followup free of disease for 6 months (Video 1).

Video 1: Bone Spect images showing increased radioactivity in left maxillary sinus wall in 3D. 


\section{Discussion}

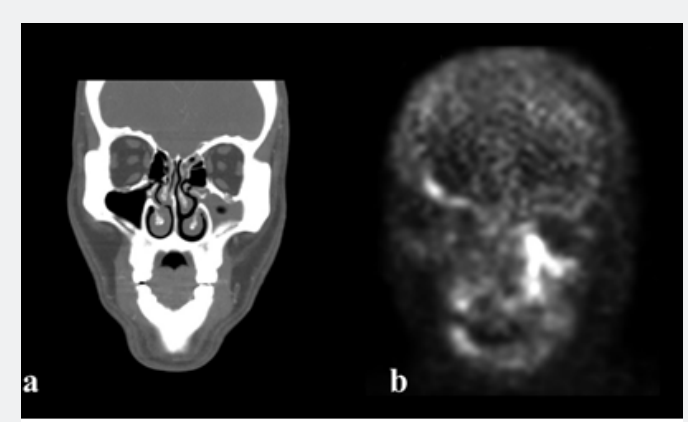

Figure 2: a) Maxillofacial CT showing the inflammatory soft tissue mass in left maxillary sinus in sagittal plane. b) Bone Spect image showing increased radioactivity in left maxillary sinus wall.

Medullary thyroid cancer is rare, accounting for 1-2\% of all thyroid cancers [2]. Distant metastases of medullary thyroid cancer are usually located at liver, lungs, bones and less frequently in brain and skin [3]. Bone metastases may be either osteolytic or osteoblastic on bone scintigraphy. The differential diagnosis may include calcific paranasal sinus malignancies [4] or metastatic spread of the nose and paranasal sinuses malignancies [5,6]. Additionally, renal cell carcinoma, lung, breast, thyroid and prostate carcinoma may display paranasal sinus metastases [5,6]. High radioactivity uptake in maxillary sinusitis is rarely found in bone scintigraphy (Figure 2). Bone scintigraphy has been used for the localization and identification of the inflammation extending to the maxillary sinus wall in early periods [7]. However, ethically, a non-complicated maxillary sinusitis patient without any malignancies does not require bone scintigraphy regarding the radiation dose given to the patient [1]. In our case, the maxillary sinusitis wall uptake is a rare and incidental finding in a patient with MEN 2A.

\section{References}

1. Van den Wyngaert T, Strobel K, Kampen W, Kuwert T, Van der Bruggen W, et al. (2016) The EANM practice guidelines for bone scintigraphy. European journal of nuclear medicine and molecular imaging 43(9): 1723-1738.

2. Cabanillas ME, McFadden DG, Durante C (2016) Thyroid cancer. The Lancet 388(10061): 2783-2795.

3. Leboulleux S, Baudin E, Travagli JP, Schlumberger M (2004) Medullary thyroid carcinoma. Clinical endocrinology 61(3): 299-310.

4. Bossi P, Farina D, Gatta G, Lombardi D, Nicolai P, Orlandi E (2016) Paranasal sinus cancer. Critical reviews in oncology/hematology 98: 45-61.

5. Ravindra P, Viswanatha B (2018) Metastatic Lymphoma of the Paranasal Sinuses. Glob J Otolaryngol 16(4).

6. Kusunoki T, Homma H, Kidokoro Y, Yanai A, Ikeda K, et al. (2015) A case of maxillary bone metastasis from lung cancer. Clinics and practice 5(4): 819.

7. Nishimura T, Iizuka T (2002) Evaluation of the pathophysiology of odontogenic maxillary sinusitis using bone scintigraphy. International journal of oral and maxillofacial surgery 31(4): 389-396.

\section{Your next submission with Juniper Publishers will reach you the below assets}

- Quality Editorial service

- Swift Peer Review

- Reprints availability

- E-prints Service

- Manuscript Podcast for convenient understanding

- Global attainment for your research

- Manuscript accessibility in different formats ( Pdf, E-pub, Full Text, Audio)

- Unceasing customer service

Track the below URL for one-step submission https://juniperpublishers.com/online-submission.php 